\title{
Influence of Climate Variability on the Prevalence of Dengue Fever in Mandera County, Kenya
}

\author{
Ndiwa Joseph Kimtai* $\quad$ Dr. James K.A. Koske Prof. Michael Koech \\ School of Environmental Studies, Kenyatta University, PO box 43844 00100, Nairobi, Kenya
}

\begin{abstract}
Climate variability affects human health by influencing processes that facilitate transmission of infectious diseases. This study aimed at investigating the influence of temperature and precipitation variability on the prevalence of Dengue fever in Mandera County from 1985 to 2014. 196 randomly selected respondents drawn from households within three health facilities' catchments were interviewed. Meteorological data was used to describe climate variability while Dengue fever was described using data obtained from health records at El Wak Sub County Hospital, Kotulo Health centre and ADRA Hospital. Results showed that temperature significantly varied $(\mathrm{t}=7.60$, $\mathrm{DF}=29, \mathrm{p}=0.0001)$. Precipitation equally varied $(\mathrm{t}=5.660, \mathrm{DF}=29, \mathrm{p}=0.0001)$. Overall temperature increase was by $0.53^{\circ} \mathrm{C}$ while annual precipitation amounts increased by $77.1 \mathrm{~mm}$. There was an insignificant correlation in Dengue fever occurrence with climate variability ( $\mathrm{r}$ value of 0.087 ). The study concluded that climate variability was not significant in Dengue fever transmission in Mandera South Sub County.
\end{abstract}

Keywords: arboviral disease, climate variability, dengue fever, impact, pathogen, prevalence

DOI: $10.7176 / \mathrm{JEES} / 9-3-06$

Publication date:March $31^{\text {st }} 2019$

\section{Introduction}

It is projected that the global average temperature will rise by between $1.1-6.4^{\circ} \mathrm{C}$ by 2099 as compared to 1980 1999 (IPCC, 2007). This rise is projected to seriously impact on human health (Costello, 2009). It will be a risk factor for Dengue fever which is becoming more endemic in tropical regions (Shuman, 2010). Close to 2.5 billion people inhabit endemic areas while about 120 million people usually travel to affected areas annually with estimates showing that 50-100 million Dengue fever infection cases occur every year (WHO, 2006). Dengue incidences are seasonal, increasing during months of highest temperature and precipitation (Sutherst, 2004). Seasonal and inter-annual variations of Dengue fever epidemics coincide with seasonal and inter-annual variations of climatic conditions. The prevalence of Dengue fever generally peaks at the onset and immediately after the rainy season (Degallier et al., 2012). Relative humidity, rainfall and temperature are suggested to majorly influence the survival of Aedes aegypti and the potential occurrence of Dengue fever outbreaks (Patz, 2005). Temperature affects pathogen replication, maturation and period of infectivity. Warmer temperatures favour increased activity and reproduction and reduce the incubation period for Ae. aegypti larvae, therefore resulting in improved capacity to produce more offspring. Thus, climate variability is clearly linked to increased transmission potential and occurrence of Dengue fever (Barbazan, 2010). Only few studies on the impacts of climate variability on Dengue fever prevalence have been conducted (Johansson, 2009). Eastern African countries have repeatedly experienced Dengue fever outbreaks for several decades (Baba et al., 2016). These outbreaks have occurred in more than half of the countries and nearly all the islands of the Indian Ocean since 1823 to date (Tsetsarkin et al., 2016). In Kenya, Dengue fever is prevalent in Mombasa and Mandera counties with Mombasa County first reporting Dengue fever outbreak in 1982 (Masila et al., 2013). Cases reported in Mandera County in 2011 affected approximately 1300 people (Centre for Disease Control, 2013). Among the response measures that were been put in place include health education to sensitize community members and health workers but challenges still exist (CDC, 2013). Data on Dengue fever in Mandera County is still inadequate as there are no proper patient attendance records (Masila et al., 2013). This study examined cases of Dengue fever observed under different climatic conditions.

\section{Methods}

The study was conducted in Mandera South Sub County of Mandera County which is among the five sub counties of Mandera County in North Eastern region of Kenya. It lies within longitudes $40^{\circ} 14^{\prime} \mathrm{E}$ and $40^{\circ} 18^{\prime} \mathrm{E}$ and latitudes $2^{\circ} 02^{\prime} \mathrm{N}$ and $2^{\circ} 08^{\prime} \mathrm{N}$ at an average altitude of 386 metres above sea level (Independent Electoral and Boundaries Commission, 2012). The study adopted a descriptive survey design a descriptive survey design. However, it contained some data that was analysed quantitatively thus employing some quantitative and analytical techniques. This involved collection of thirty years' data from Kenya Meteorological Department on precipitation and temperature from 1985 to 2014 which was used to describe climate variability. Dengue fever data for the same period was also obtained from hospital records from three hospitals. Other data was collected from 196 randomly selected adult household members in the health facilities' patient catchment who were interviewed using open and closed ended questionnaires. The study used simple random sampling to select the 196 respondents from 196 
households; 66 from El Wak Hospital catchment, 65 from ADRA Hospital catchment and 65 from Kotulo Health centre catchment. This was considered appropriate so as to ensure equal representation of the entire study area and by the need to achieve proportionality of all the health facility catchments. Only one adult local residents of above the age of 40 years was chosen since climate is long term hence the respondents must have been old enough to gain knowledge on climate variability and must have had enough experience of Dengue fever. Patients were excluded since the study was interested in finding out the pattern of occurrence of Dengue fever in relation to specific climatic events which could be obtained from the hospital records and the 196 respondents. The demographic characteristics of the respondents were considered important as this determined their suitability for providing relevant information as required by the research study. Their gender, level of education, and their duration of stay within the area of study was also considered. This was significant because knowledge on climate variability and its influence on Dengue fever prevalence required residents who had been in the study area for a long period and could have witnessed this occurrence. Some could have been new in the area to adequately gain knowledge on climate variability and its influence on Dengue fever prevalence within the area. It was however data from Kenya Meteorological Department on climate variability and data on Dengue fever from the hospital records for the period 1985-2014 that was used for hypothesis testing. Descriptive, quantitative and analytical techniques were used in analysis. One-way ANOVA was used to test the data for normality then two sample ttests, chi-square test, and correlation techniques were used for detailed data analysis. Independent tests were also conducted for equality of variances and equality of means for temperature and precipitation using Levene's test and T-test respectively. Significance levels of all tests of significance and hypothesis were set at $95 \%$.

\section{Results and discussion}

Before examining the influence of climate variability on the prevalence of Dengue fever, it was first important to assess how climate had varied. Precipitation and temperature data were analysed to test the null hypothesis that climate variability had not occurred in Mandera South Sub County between 1985 and 2014.

\subsection{Temperature variability between 1985 and 2014}

Monthly average temperature was computed using monthly minimum and maximum temperature data. Annual averages were then computed from the monthly average temperatures which were then used to analyse the trends of temperature in Mandera South Sub County between 1985 and 2014. The annual average temperatures during the period 1985-2014 revealed that Mandera South Sub County was slowly warming as illustrated in Figure 1. The mean annual temperature in the area has been marginally increasing. The lowest average temperature recorded was $29^{\circ} \mathrm{C}$ in 1985 and 1989 while the highest was $30.4^{\circ} \mathrm{C}$ in 1997 . Average annual temperatures have generally been increasing from 1985 to 2014. The long-term average annual temperature recorded in Mandera South Sub County for the 30 year period was $29.8^{\circ} \mathrm{C}$.

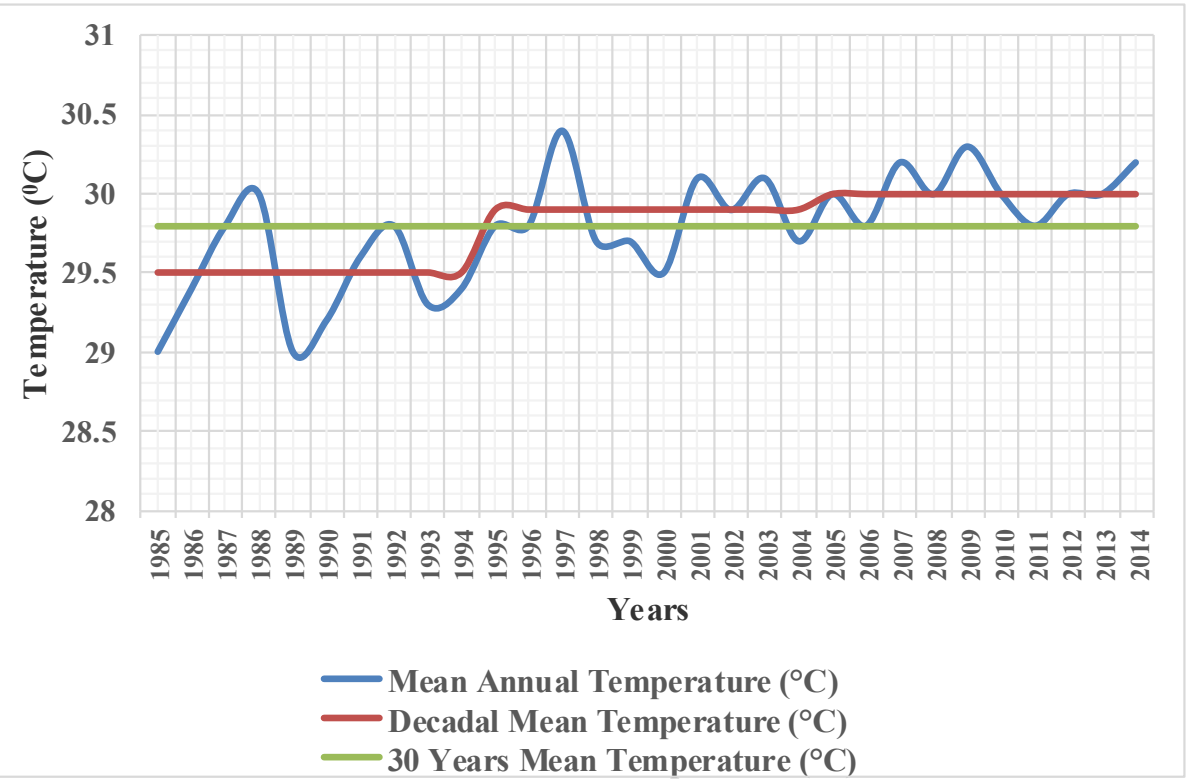

Figure 1: Mean annual temperature trend in Mandera South Sub County between 1985- 2014

Results showed that average annual temperature has been rising with annual variability each year as shown by the line graph. Out of the 30 years, $63.3 \%(n=19)$ recorded mean annual temperatures above the analysis period mean. $68.4 \%(n=13)$ of these years occurred during the last decade. The 11 years with mean annual temperatures below the long-term mean recorded an average annual temperature of $29.4^{\circ} \mathrm{C}$ while the 19 years that 
recorded temperatures above the long-term mean had an average annual of $30.0^{\circ} \mathrm{C}$. The significance of temperature variability was tested for equality of variances and equality of means using Levene's test and t-test respectively and results presented in table 1 :

Table 1: Test of equality of variances and equality of means for temperature

Levene's Test for Equality of Variances $\quad$ t-test for Equality of Means

\begin{tabular}{|c|c|c|c|c|c|c|c|c|c|}
\hline & & $\mathbf{F}$ & Sig. & $\mathbf{T}$ & DF & $\begin{array}{l}\text { Sig. (2- } \\
\text { tailed) }\end{array}$ & $\begin{array}{l}\text { Mean } \\
\text { Difference }\end{array}$ & $\begin{array}{l}95 \% \text { Co } \\
\text { Interval } \\
\text { Differen } \\
\text { Lower }\end{array}$ & $\begin{array}{l}\text { dence } \\
\text { the } \\
\text { Upper }\end{array}$ \\
\hline \multirow{2}{*}{$\begin{array}{l}\text { Mean annual } \\
\text { temperature }\end{array}$} & $\begin{array}{l}\text { Equal } \\
\text { variances } \\
\text { assumed }\end{array}$ & 3.9834 & \multirow[t]{2}{*}{0.0550} & 7.6000 & 29 & 0.0001 & -0.6250 & -0.0793 & -0.6845 \\
\hline & $\begin{array}{l}\text { Equal } \\
\text { variances not } \\
\text { assumed }\end{array}$ & & & 6.9290 & 17 & 0.0001 & -0.6250 & -0.8152 & -0.4843 \\
\hline
\end{tabular}

The significant test results were $\mathrm{t}=3.9834, \mathrm{df}=29, \mathrm{p}=0.001$. The "Sig. (2-tailed)" is less than 0.05. Therefore a conclusion can be made that the means are significantly different. Temperatures for the years 1985 to 1996 remained below average except in 1987, 1988, 1992 and 1995, fluctuated around the mean from 1997-2000 then remained above average from 2001-2014 except in 2004 with an increasing trend and annual variability. A major temperature rise and variability occurred as from the year 2007 to 2014 when temperatures remained above $30^{\circ} \mathrm{C}$ except in 2011 when the temperature recorded was $29.8^{\circ} \mathrm{C}$. An analysis of 10 years moving average for temperature for the entire analysis period showed temperatures in Mandera South Sub County increased at an annual rate of $0.0177^{\circ} \mathrm{C}$ and cumulatively rose by $0.53^{\circ} \mathrm{C}$ for the three decades as illustrated in Table 2 . This magnitude of temperature rise is in agreement with IPCC 2001 report that the earth has warmed by $0.75^{\circ} \mathrm{C}$ in the last 100 years globally and that the global average temperature will rise by between $1.1-6.4^{\circ} \mathrm{C}$ by the end of the $21^{\text {st }}$ century as compared to 1980-1999 (IPCC, 2007).

Table 2: Annual average temperature trend in Mandera South Sub County

\begin{tabular}{llc}
\hline Period & Average Temp. $\left({ }^{\circ} \mathbf{C}\right)$ & Magnitude of Increase $\left({ }^{\circ} \mathbf{C}\right)$ \\
\hline $1985-1994$ & 29.50 & - \\
$1995-2004$ & 29.90 & 0.4000 \\
$2005-2014$ & 30.03 & 0.1300 \\
\hline Overall increase & - & $\mathbf{0 . 5 3 0 0}$ \\
Annual increase rate & - & $\mathbf{0 . 0 1 7 7}$ \\
\hline
\end{tabular}

Further analysis of the annual maximum and minimum temperatures for Mandera South Sub County showed that temperature rise between 1985 and 2014 was majorly contributed by a sharp increase in the minimum annual temperature component as illustrated in Table 3.

Table 3: Mandera South Sub County's annual minimum and maximum temperature trend between 1985 and 2014

\begin{tabular}{lllll}
\hline Period & $\begin{array}{l}\text { Minimum } \\
\text { Temp. }\left({ }^{\circ} \mathbf{C}\right)\end{array}$ & $\begin{array}{l}\text { Magnitude of } \\
\text { increase }\left({ }^{\circ} \mathbf{C}\right)\end{array}$ & $\begin{array}{l}\text { Maximum } \\
\text { Temp. }\left({ }^{\circ} \mathbf{C}\right)\end{array}$ & $\begin{array}{l}\text { Magnitude of } \\
\text { increase }\left({ }^{\circ} \mathbf{C}\right)\end{array}$ \\
\hline $1985-1994$ & 24.10 & - & 34.70 & - \\
$1995-2004$ & 24.30 & 0.20 & 35.40 & 0.70 \\
$2005-2014$ & 24.30 & 0.10 & 35.60 & 0.20 \\
\hline Overall increase & - & $\mathbf{0 . 3 0}$ & - & $\mathbf{0 . 9 0}$ \\
Annual increase rate & - & $\mathbf{0 . 0 3}$ & - & $\mathbf{0 . 0 1}$ \\
\hline
\end{tabular}

The minimum annual temperature increased by $0.9^{\circ} \mathrm{C}$ with an annual increase rate of $0.03^{\circ} \mathrm{C}$ while the maximum annual temperatures rose by $0.3^{\circ} \mathrm{C}$ with annual increase rate of $0.01^{\circ} \mathrm{C}$ between 1985 and 2014 . The substantial annual average temperature increase witnessed between 1995 and 2004 was majorly driven by the annual minimum temperature which increased by of $0.7^{\circ} \mathrm{C}$ while the maximum temperatures increased by $0.2^{\circ} \mathrm{C}$ only for the same period. The increase rate of the minimum annual temperature between 1995 and 2004 contributed majorly to the overall annual average temperature increase as opposed to the average annual maximum temperature. However, the rate of increase of both the average annual minimum and maximum temperature between 2005 and 2014 was negligible but both maximum and minimum temperature trends show some remarkable warming. The diurnal range of temperature also remained relatively high. As of between 2005 and 2014, the average maximum annual temperature was $35.6^{\circ} \mathrm{C}$ while the minimum average annual temperature was $24.3^{\circ} \mathrm{C}$. The range was thus 
$11.3^{\circ} \mathrm{C}$. These findings corroborated the GoK (2010) climate report that revealed in its findings that temperature trends in Kenya have slowly been increasing during the past 50 years but the increase is contributed more by the maximum temperatures than the minimum temperatures. This is also in agreement with the IPCC 2007 report.

\subsection{Precipitation variability between 1985 and 2014}

Analysis showed that precipitation has been rising slowly but with variations annually as illustrated in Figure 2 . The mean precipitation recorded for the 30 years was $283.3 \mathrm{~mm}$ but there were annual variations in the individual years. $64.9 \mathrm{~mm}$ was the lowest annual precipitation amount in 2001 while the highest precipitation amount was $987.5 \mathrm{~mm}$ recorded in 1997 which was a sharp increase from $126.5 \mathrm{~mm}$ in 1996.

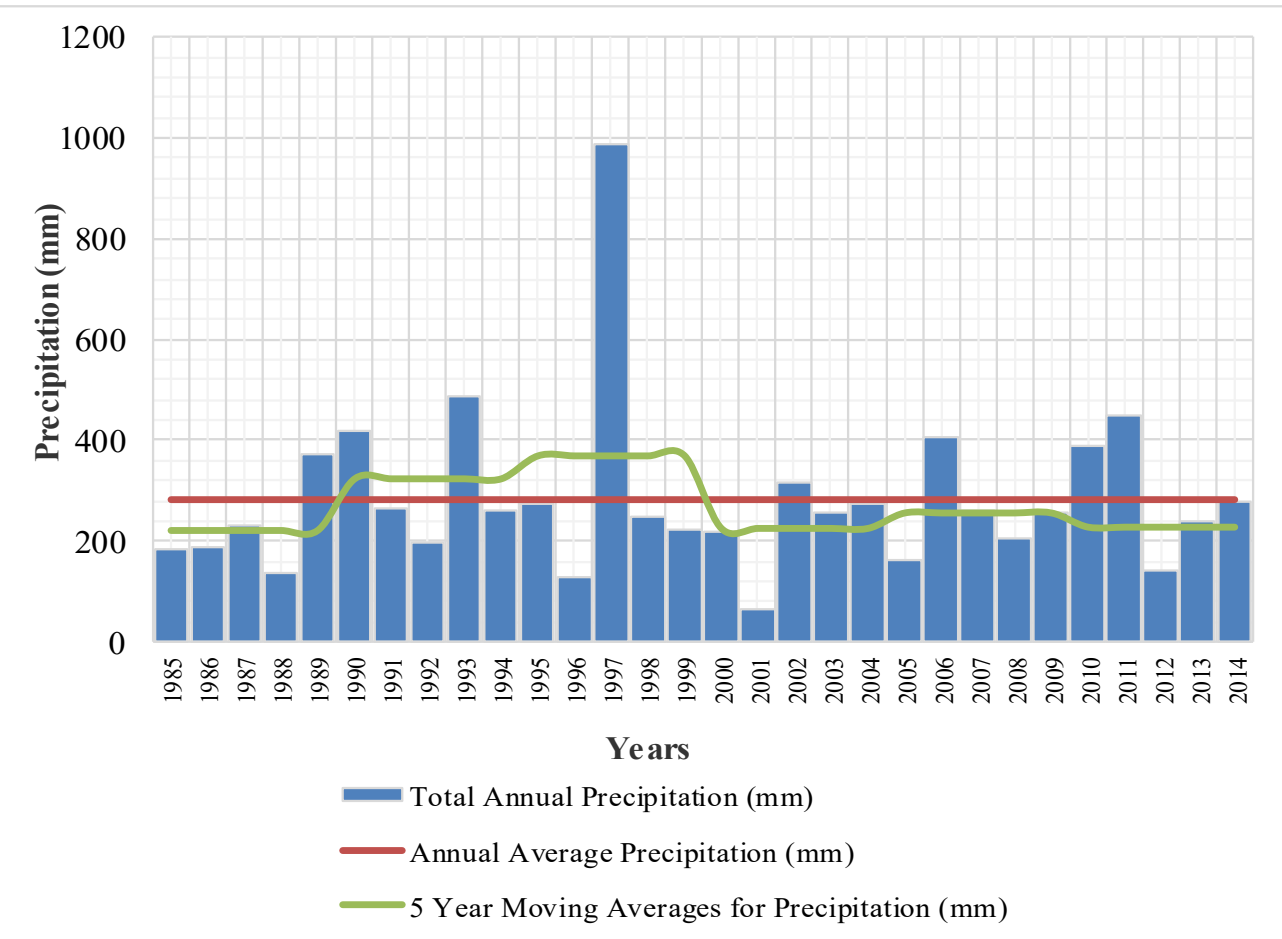

Figure 2: Total annual precipitation for Mandera South Sub County between 1985 and 2014

Precipitation fluctuations characterizing climate variability were revealed from deviations from the 30 years average precipitation as shown in figure 3 .

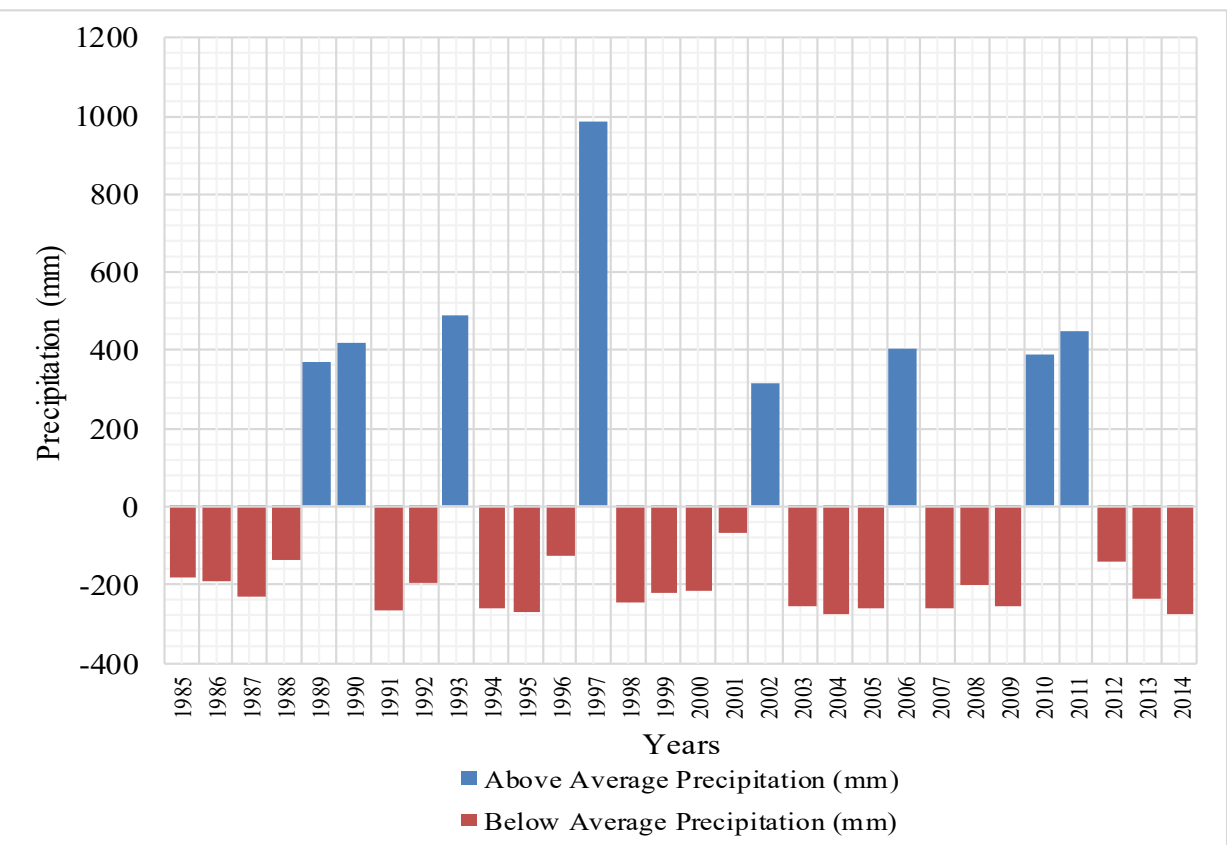

Figure 3: Annual precipitation fluctuations in Mandera South Sub County between 1985 and 2014 
Results showed that $26.7 \%(n=8)$ out of the 30 years under investigation recorded above average total annual precipitation amounts. Similarly, the area recorded 8 years of extremely below average precipitation sufficing as possible drought years. According to results in Figure 3, Mandera South Sub County recorded 7 drought seasons during the period 1985-2014 which occurred in the following sequence: 1985-1986, 1988, 1992, 1996, 2001, 2005 and 2012. The 8 years with mean annual precipitation above the long-term mean recorded an average annual precipitation of $478.31 \mathrm{~mm}$ while the 22 years that recorded precipitation below the long-term mean had an average annual precipitation of $208.62 \mathrm{~mm}$. The significance of precipitation variability was tested for equality of variances and equality of means using Levene's test and t-test respectively and results presented in table 4:

Table 4: Test of equality of variances and equality of means for precipitation

\begin{tabular}{|c|c|c|c|c|c|c|c|c|}
\hline \multicolumn{3}{|c|}{ Levene's Test for Equality of Variances } & \multicolumn{6}{|c|}{ t-test for Equality of Means } \\
\hline & $\mathbf{F}$ & Sig. & $\mathbf{t}$ & DF & $\begin{array}{l}\text { Sig. (2- } \\
\text { tailed) }\end{array}$ & $\begin{array}{l}\text { Mean } \\
\text { Difference }\end{array}$ & $\begin{array}{l}95 \% \mathrm{C} \\
\text { Interva } \\
\text { Differe } \\
\text { Lower }\end{array}$ & Upper \\
\hline $\begin{array}{ll}\text { Mean } & \text { Equal variances } \\
\text { annual } & \text { assumed } \\
\text { ppt. } & \text { Equal variances not } \\
\text { assumed }\end{array}$ & 5.530 & 0.03 & $\begin{array}{l}5.66 \\
3.55\end{array}$ & $\begin{array}{l}29 \\
7\end{array}$ & $\begin{array}{l}0.000 \\
0.009\end{array}$ & $\begin{array}{l}269.60 \\
269.6\end{array}$ & $\begin{array}{l}172.24 \\
92.03\end{array}$ & $\begin{array}{l}367.13 \\
447.34\end{array}$ \\
\hline
\end{tabular}

The significant test results were $\mathrm{t}=5.530, \mathrm{df}=29, \mathrm{p}=0.001$. The "Sig. (2-tailed)" is less than 0.05 . Therefore a conclusion can be made that the means are significantly different. However, the mean annual precipitation of the years that recorded precipitation above the long-term mean had a higher mean than the mean annual precipitation of the years that recorded temperatures below the long-term mean.

Considering the role of El Niño-Southern Oscillation effect, 1986, 1987, 1991, 1997, 2002, 2004, 2006, 2009 are categorized as El-Niño years while 1985, 1988, 1998, 2000, 2007, and 2010 are categorized as La-Niña years (NCEP, 2013). The anomalies shown by the findings may therefore be attributed to these meteorological events rather being wholly seen as an effect of climate variability. The droughts depicted and the excessive precipitation amounts recorded in 1989, 1990, 1993, 1997, 2002, 2006, 2010 and 2011 can therefore be attributed to the effect of the El Niño-Southern Oscillation.

To further investigate precipitation trends in Mandera South Sub County, five-year moving averages were computed to examine precipitation trend after every five years. The results were presented in Table 5.

Table 5: Five-year moving averages for precipitation in Mandera South Sub County between 1985 and 2014

\begin{tabular}{lllll}
\hline Period & $\begin{array}{l}\text { Mean Ptt. } \\
\text { Amounts }(\mathbf{m m})\end{array}$ & $\begin{array}{l}\text { Deviations from } \\
\text { the 30 years mean } \\
\mathbf{( 2 8 3 . 3 m m})\end{array}$ & $\begin{array}{l}\text { Magnitude of } \\
\text { increase from } \\
\text { previous 5 years }\end{array}$ & Trend \\
\hline $1985-1989$ & 221.9 & -61.4 & - & - \\
$1990-1994$ & 324.9 & 41.6 & 103.0 & Increase \\
$1995-1999$ & 370.9 & 87.6 & 46.0 & Increase \\
$2000-2004$ & 226.1 & -57.2 & -144.8 & Decrease \\
$2005-2009$ & 257.0 & -26.3 & 30.9 & Increase \\
$2010-2014$ & 229.0 & -54.3 & 42.0 & Increase \\
\hline Total increase & & & $\mathbf{7 7 . 1}$ & Increase \\
\hline
\end{tabular}

Results showed that Mandera South Sub County recorded an increase in precipitation amounts of $77.1 \mathrm{~mm}$ between 1985 and 2014, but with annual variations depicting climate variability. Two of the six 5-year moving average periods (1990-1994 and 1995-1999) experienced higher precipitation amounts than the 30 years mean annual precipitation.

\subsection{Annual Dengue fever prevalence rates in Mandera South Sub County between 1985 and 2014}

A review of the surveillance data from the hospital records at El Wak Sub County Hospital, ADRA Hospital and Kotulo Health centre showed that the available data was so scanty. Number of cases and outbreak reports from 1985 and 2014 existed although they were not complete. The findings were presented in Figure 4. 


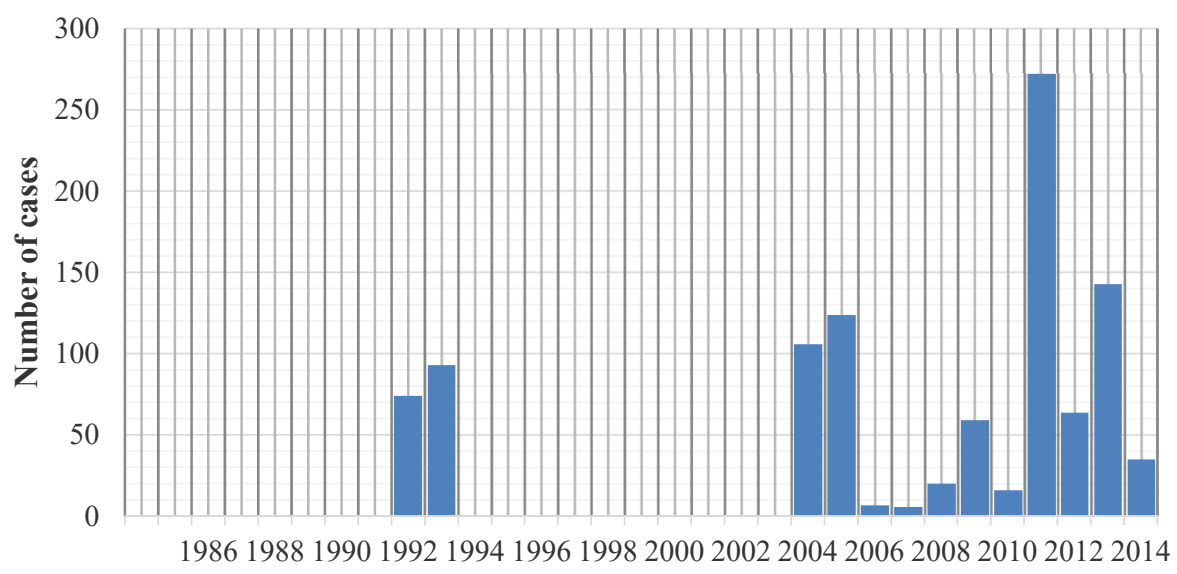

Years

Figure 4: Annual Dengue fever prevalence rates in Mandera South Sub County between 1985 and 2014

The findings revealed that between 1985 and 2014, Mandera South Sub County experienced 13 years of Dengue fever of various magnitudes. 1992 recorded 74 Dengue fever cases, 1993 recorded 93 cases, 2004 recorded 106 cases, 2005 recorded 124 cases, 2006 recorded 7 cases, 2007 recorded 6 cases, 2008 recorded 20 cases, 2009 recorded 59 cases while 2010 recorded 16 cases. Highest Dengue fever cases were treated at all the three health facilities in 2011 ( 272 cases) and 2013 (143 cases). 2012 and 2014 recorded 64 and 35 cases respectively. 2011 and 2013 were characterized as severe outbreak years. The years that experienced high Dengue fever prevalence rates are 2004, 2005, 2011 and 2013. There were no records showing the total number of cases between 1985 and 1991 and also between 1994 and 2003 therefore suggesting limited surveillance efforts. All through, the occurrence of Dengue fever was in form of outbreaks. The years between the outbreaks could have experienced low-level endemic transmissions, which may have gone unrecognized.

\subsection{Relationship between Dengue fever prevalence and annual climate variability}

The study also sought to establish the annual relationship between Dengue fever cases and temperature and precipitation variability between 1985 and 2014. The results were presented in Figure 5.

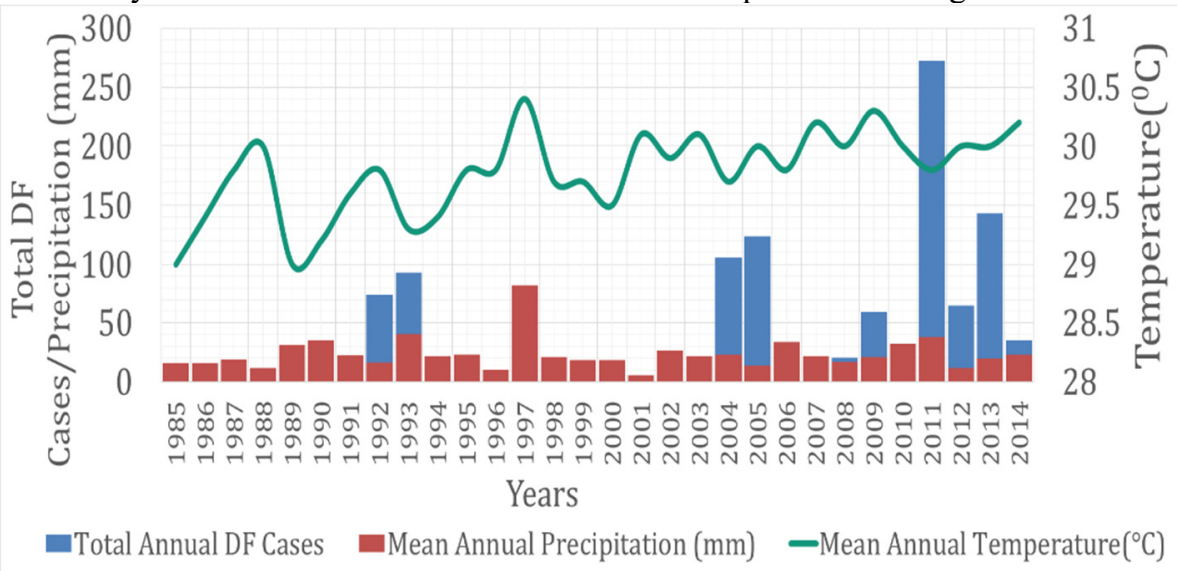

Figure 5: Annual comparison of Dengue fever cases with climate variability between 1985 and 2014

The study revealed that in 1992 when Dengue fever cases were 74, the average annual precipitation was strikingly below average. Average annual temperature was $29.8^{\circ} \mathrm{C}$. In 1993, total Dengue fever cases were 93. Precipitation was above the annual average but temperatures were below the annual average. 2004 recorded 106 Dengue fever cases with $22.8 \mathrm{~mm}$ precipitation and $29.7^{\circ} \mathrm{C}$ temperature which were both below the annual average. 2005 recorded 124 cases with strikingly below average precipitation of $13.4 \mathrm{~mm}$ and above average annual temperature of $30^{\circ} \mathrm{C} .2006$ and 2007 recorded only 7 and 6 cases respectively. Both precipitation and temperature were above average in 2006 but were below average in 2007.2008 and 2009 recorded 20 and 59 cases respectively with below average annual precipitation of $17 \mathrm{~mm}$ and $21.2 \mathrm{~mm}$ and above average temperature of $30^{\circ} \mathrm{C}$ and $30.3^{\circ} \mathrm{C}$. In 2010, both precipitation and temperature were above the annual average but Dengue fever cases were low at only 16. 2011 recorded highest cases throughout the study period with 272 cases. Annual average precipitation was also the second highest in all the Dengue fever years at $37.5 \mathrm{~mm}$ while temperature was $29.8^{\circ} \mathrm{C}$. The subsequent 
years didn't record high Dengue fever cases except 2013 that recorded 143 cases. Precipitation was below average in these years but temperatures remained relatively high at $30^{\circ} \mathrm{C}$ for 2012 and 2013 and $30.2^{\circ} \mathrm{C}$ for 2014 .

The significance of climate variability and the pattern of occurrence of annual Dengue fever was tested by regression analysis, correlation analysis and ANOVA. The following hypothesis stated in null form was tested:

$H_{0}$ : Annual climate variability has no significant influence on the prevalence of Dengue fever in Mandera South Sub County.

Correlation analysis was conducted to test the association between annual Dengue fever cases and temperature and precipitation. Regression analysis was conducted to ascertain the degree of Dengue fever occurrence that is explained by variability in temperature and precipitation in Mandera South Sub County. The results were presented in table 6:

Table 6: Correlation of climate variability and Dengue fever prevalence

\begin{tabular}{lllll}
\hline Correlation & & Precipitation & Temperature & Dengue fever cases \\
\hline \multirow{2}{*}{ Precipitation } & Pearson Correlation & 1 & 0.323 & 0.058 \\
& Sig. (2-tailed) & & 0.206 & 0.824 \\
Temperature & Pearson Correlation & 0.323 & 1 & 0.080 \\
& Sig. (2-tailed) & 0.206 & & 0.761 \\
\multirow{2}{*}{ Dengue fever cases } & Pearson Correlation & 0.058 & 0.080 & 1 \\
& Sig. (2-tailed) & 0.824 & 0.761 & \\
\hline
\end{tabular}

The correlation analysis between Dengue fever and precipitation variability present a small correlation value of 0.058 and a large p-value of 0.824 . Dengue fever and temperature also present a small correlation coefficient value of 0.080 and a large $p$ value of 0.761 . In both cases, the p values are greater than 0.05 . A conclusion was drawn that no significant correlation exists between climate variability and the prevalence of Dengue fever cases. However, the correlation was positive, indicating co-variation. Table 7 shows regression analysis of combined climate variables and the pattern of occurrence of Dengue fever.

Table 7: Regression analysis of combined climate variables and the pattern of occurrence of Dengue fever

\begin{tabular}{lllll}
\hline Regression & R & R Square & Adjusted R Square & Std. Error of the Estimate \\
\hline 1 & $0.087^{\text {a }}$ & 0.008 & -0.134 & 0.418001 \\
\hline
\end{tabular}

a. Predictors: (Constant), Temperature, Precipitation

The model summary statistics presents an $\mathrm{R}$ value of 0.087 . This proves that a weak correlation exists between total Dengue fever cases and climate variability. The findings also presented an R squared value 0.008 which is equivalent to $0.8 \%$. This indicated that climate variability explained only $0.8 \%$ of the variation in Dengue fever in Mandera South Sub County. Table 8 presents the coefficients of the model.

Table 8: Coefficients of the model

\begin{tabular}{lll|lll}
\hline \multicolumn{1}{c|}{$\begin{array}{l}\text { Coefficients Model } \\
\text { Unstandardized } \\
\text { Coefficients }\end{array}$} & $\begin{array}{l}\text { Standardized } \\
\text { Coefficients }\end{array}$ & t & Sig. \\
\hline & B & Std. Error & Beta & \\
\hline (Constant) & 29.704 & .274 & & 108.417 & .000 \\
1 precipitation & .000 & .002 & .036 & .129 & .899 \\
Temperature & .003 & .012 & .068 & .242 & .813 \\
\hline
\end{tabular}

The regression model obtained is as follows;

Dengue fever $=29.704+0.0001 \mathrm{X}_{1}+0.003 \mathrm{X}_{2}+\mathrm{e}$

From the findings, it is evident that although the climate variability accounts for small occurrence of Dengue fever, temperature variability had a higher effect on Dengue fever occurrence than precipitation variability.

\section{Conclusion}

There are so many scientific opinions attempting to explain the extent of the occurrence of climate change, its causes and its probable consequences (IPCC, 2007). However, there exists a consensus that the earth's climate system is unequivocally warming therefore posing a major challenge to our global society (Reiter, 2001). Results of this study showed that Mandera South Sub County is experiencing climate variability, similar to the rest of the country and probably the rest of the world. There is therefore need to prepare for mitigation and adaptation. The findings of this study revealed that although statistical correlation could be established between climate variability and Dengue fever prevalence in Mandera South Sub County, lack of long term high quality data set was a setback. This is because results from other studies within the tropical regions have produced strong evidences of climateDengue fever relationships. Climate variability will continue to occur in the future years and weather or climate 
related risks for Dengue fever prevalence remain high in Mandera South Sub County especially that the environment conditions are more conducive for Aedes Aegypti that transmits Dengue fever. The findings of this study revealed transmission of Dengue fever as a consequence of seasonal climate variability thus provides forewarning to the relevant authorities to take appropriate actions to prevent Dengue fever prevalence particularly in periods of high temperature and at the onset of rainy seasons.

\section{References}

Baba, M., Jandouwe V. and Masiga, D.K. (2016). Repetitive dengue outbreaks in East Africa: A proposed phased mitigation approach may reduce its impact. Reviews in medical virology, 26(3), 183-196.

Barbazan, P.L. (2010). Modelling the effect of temperature on transmission of Dengue. Medical and Veterinary Entomology, 24, 66-73.

Centre for Disease Control (2013). The Dengue fever response in Mandera East Sub County from 10th to 24th February 2013. Nairobi, Kenya.

Costello, A. (2009). Managing the health effects of climate change: Lancet and University College London Institute for Global Health Commission. Lancet, 373, 169-173.

Degallier, N., Lucio, P.S., Servain, J. A., Hannart, B., Durand, R. N., Souza, D. and Ribeiro, Z.M., (2012). The influence of local environment on the Aedes aegypti aging and mortality. Case study: Fortaleza-CE, Brazil. Journal of Vector Ecoogy, 37, 428-441.

GoK (2010). National climate change response strategy-2010. Nairobi, Kenya: Government Printers.

Independent Electoral and Boundaries Commission (2012) IEBC Final Report of Boundaries of Constituencies and Wards. Nairobi, Kenya. Accessed on September 16 $6^{\text {th }}, 2014$ from http://eaclj.org/constituition/20constituition-featurearticles/112-iebc-s-report-on-boundaries.html

IPCC (2007). Climate Change: The Physical Science Basis: Contribution of Working Group I to the Fourth Assessment Report of the Intergovernmental Panel on Climate Change. Cambridge: Cambridge University Press.

Johansson, M.A. (2009). Local and global effects of climate on Dengue transmission in Puerto Rico. Neglected Tropical Diseases, 3, 382.2007/2008.

Masila, C., Misiko, C., Rotich, J., Kungu, J. and Gikundi, S. (2013). Alarm over Zoonotic Disease Out breaksFocus shifts to the One Health approach: The East Africa Public Health Lab Network Newsletter, Kenyatta National Hospital.

Patz, J.A. (2005) Impact of regional climate change on human health. Nature, 438, 310-317.

Shuman, E.K. (2010). Global climate change and infectious diseases. New England Journal of Medicine, 362, 161163

Sutherst, R.W. (2004). Global change and human vulnerability to vector-borne diseases. Clinical Microbiology Reviews, 17, 136-173.

WHO (2006). Scientific Working Group Report on Dengue. Geneva, Switzerland. 